\title{
Ironiczny autoportret Stanisława Barańczaka
}

Lech Giemza 


\section{NAPIS Seria XIV 2008}

\section{Lech Giemza}

\section{Ironiczny autoportret Stanisława Barańczaka}

1.

$\mathrm{U}$

dowadnianie, że Barańczak jest poetą obdarzonym poczuciem humoru, byłoby wyważaniem już otwartych drzwi. Autor Chirurgicznej precyzji i Tryptyku z betonu, zmeczenia i śniegu, ale także Tablicy z Macondo i Ksiażek najgorszych, co krok daje się poznać jako mistrz ironicznego dystansu i kpiny. Zwraca na to uwage Joanna Dembińska-Pawelec:

Ironia, zakradająca się do każdego wiersza, towarzysząca postaci podmiotu i bohaterów (w Drobnomieszczańskich cnotach, Kontrapunkcie), opisom zbiorowości (np. obserwatorom ptaków, drużyny koszykarskiej), wkraczająca w sztucznie uformowany świat natury (Obserwatorzy ptaków) pozwala na wytworzenie się dystansu między ,ja” lirycznym a czytelnikiem. Tà odrobina krytycznego oddalenia uwalnia odbiorcę spod presji podmiotu i pozwala mu na indywidualne określenie własnego miejsca w perspektywie tematyki metafizycznej, filozoficznej i egzystencjalnej'.

Barańczak zdolny jest zakpić z wszystkiego i każdego, poczynając od „smutnych panów" reprezentujących reżim polityczny, a kończąc na Panu Bogu i najkrótszym wyznaniu wiary, którym miałaby być rejestracja samochodowa (słynne „ON JEST” $z$ eseju Tablica $z$ Macondo). Dostaje się również opozycjonistom (reprezentowanym chociażby przez Olgierda Krawczyka), naiwnym gościom z Zachodu (Cynthia Ka-

1 J. Dembińska-Pawelec, Światy możliwe w' poezji Stanistawa Barańczaka, Katowice 1999, s. 137. Tezy zawarte w powyższej pracy najbliższe są rozpoznaniom tu przedstawionym, przy czym autorka skupiła się na dwóch tomikach Barańczaka: Tryptyku z betonu, zmęczenia i śniegu oraz Widokówce z tego świata. 
minsky z wiersza But why?), mieszkańcom lepszego, bo demokratycznego świata (za urzędowy optymizm i polityczną naiwność chociażby), i przede wszystkim nam „Zwykłym zjadaczom chleba”.

Co jednak ważne - nigdy nie jest to śmiech raniący, intencjonalnie szkalujący czyjeś dobre imię. By uprawomocnić to ostatnie zdanie, które wymagałoby zapewne dłuższego (i nudnego przy tym) wywodu, dopowiem tylko, że komizm bohaterów wynika tu bardziej z uważnej obserwacji i zderzenia naszych wyobrażeń z konkretem, niż z dążenia do przerysowania postaci w żądanym kierunku. Śmieszność jest tutaj immanentnym składnikiem czlowieczeństwa, nie zaś bronią w walce $z$ jakkolwiek pojmowanym Innym. Dlatego nawet przedstawiciele wrogich, mrocznych sil Historii, w wierszu Dyletanci nazwani ironicznie „specjalistami”, którzy zawsze fachowo: „przetrząsali chlebaki, odklejali koperty nad parą”, przecież jednak „tłumili w sobie prywatną pasję do Rembrandta lub ichtiologii" (s. 289) ${ }^{2}$. Dowcip autora Chirurgicznej precyzji, jeżeli jest skierowany personalnie, wzbogaca raczej rysy bohatera, niż go spłyca; ukazuje go w nierozerwalnym splocie małości i wzniosłości.

W swoim artykule zamierzam skupić się jedynie na tych tekstach poetyckich, w których Szacowny Autor pisze sam o sobie z charakterystycznym dla siebie przymrużeniem oka. Jest ich nader wiele. Bohater o rysach wybitnie upodabniających go do samego poety wędruje przez teksty jak przez gabinet krzywych luster. Warto zapytać, w jaki sposób i w jakim celu poeta konstruuje swą ironiczną a u to charakterystykę. Należą do niej między innymi takie fragmenty:

ja, ekspert na skalę wschodnioeuropejską w kwestiach odmowy [zeznań i mówienia między wierszami, wielokrotny mistrz osiedla w konkurencji zdobywania miejsca [Résumé, s. 298];

[w kolejce

dobrze, że dochrapałem się własnej

kuchni, w której mogę kroić

ten baleron

[Zawrót gloury od sukcesów, s. 236];

ja, nocny marek, podejrzany okularnik, niepoprawny człowiek, nieopierzona sowa na złość i na próżno wpatrzona w ciemnotę i ciemność, ja, niewprawny jasnowidz, widzący czarno przed sobą [Utożone po ciemku, s. 240];

2 Wszystkie cytaty za: S. Barańczak, Wiersze zebrane, Kraków 2006. 
siedzę $\mathrm{w}$ komisariacie $\mathrm{z}$ brulionem własnych wierszy ukrytym (co za przezorność) w nogawce zimowej bielizny [I nikt mnie nie uprzedzit, s. 252]

Już pobieżny rzut oka na tę twórczość pozwala przypuszczać, że jednym z mechanizmów komizmu u autora Korekty twarzy jest autoprezentacja w sytuacjach trywialnych, dobrze, lub nawet nazbyt dobrze znanych zwyklym śmiertelnikom. Otrzymujemy więc następujący komunikat: „Myślicie, że poeta jest wybrańcem bogów? Nawet jeżeli tak, to nie umniejsza to jego codziennych problemów". Taka strategia sprawia, że obdarzamy autora większym kredytem zaufania. Sprawy istotne, które równocześnie porusza, też stają się nam bliższe, wspólne. Niezależnie, czy jest to kwestia odpowiedzialności za historię, czy otwarcie na Transcendencję lub sztuka otwierania się na Innego.

Nie zawsze przecież żart z samego siebie jest formą wejścia w kontakt. Ułatwia te $\dot{z}$ spojrzenie z dystansem na własne problemy. Nie da się bez podziwu spojrzeć na pełną godności postawę Barańczaka wobec własnej choroby, możliwą również dzięki pogodzie ducha:

Zaczęło się u mnie to draństwo dokładnie 20 lat temu, jeszcze przed czterdziestką. [...] Co do mnie zresztą, te pożytki duchowe z choroby nie są tak całkiem złudne: choroba mnie poniekąd duchowo zrelaksowała. Przez dwadzieścia lat od mojej Blake'owskiej iluminacji mam stale poczucie, że jestem nieprawdopodobnym szczęściarzem, jakimś businessmanem, który potrafi wykorzystać partię golfa do załatwiania interesów własnej firmy, albo farmerem $z$ wiersza Frosta, dla którego rąbanie drzew staje się rozrywką i właściwie sztuką̧ .

Żartobliwy ton pozwala uniknąć zbędnej afektacji. Ciężka choroba jest „draństwem”, nie zaś żadnym „katarktycznym doświadczeniem”, czy „dorastaniem do pełni człowieczeństwa”. „Cierpienie nie uszlachetnia, cierpienie izoluje” — stwierdza w tej samej rozmowie Barańczak, odcinając się tym samym od nazbyt często powtarzanych frazesów. $\mathrm{Z}$ tą samą pogodną rezygnacją spogląda na całą własną biografię: dzieciństwo w wierszu Lipiec 1952, dorastanie i młodzieńczy bunt w wierszu Czerwiec 1962 oraz osiągnięcie dojrzałości - „Skończyło się, dawno temu. Co? Młodość” (Wrzesień, s. 299). Bezpośredniość opisywania doświadczeń sprawia, że autor staje się jednym $z$ nas. Zauważmy, że pozornie identyczna strategia innego byłego poety nowofalowego, Adama Zagajewskiego, stawia go na diametralnie odmiennej pozycji wobec czytelnika. Gdy pisze on w Obronie żarliwości o swoim liceum, które „pasjonowało się [...] muzy-

${ }^{3}$ S. Barańczak, „Wygladało to tak, jak gdybym się nagle znalazt pośród uielkiego ogrodu”. Rozmowa z Krzysztofem Biedrzyckim, „Dekada Literacka” 2005, nr 3/4, s. 67. 
ką Elvisa Presleya, Chubby Checkera i Little Richarda”, a jeżeli należało się do grupy ambitniejszych uczniów, to "czytało się teatr absurdu” i „uwielbiało się czarną literaturę"4, to akt identyfikacji okazuje się w swej istocie aktem rezygnacji z udziału we wspólnocie. Gdy ten sam eseista przypomni nam w dodatku „ów sławny epizod, kiedy Simone Weil zatapia się w kontemplacji Rodanu"5, to pozostanie głęboko westchnąć nad swoim miejscem w szeregu. Wystarczy zresztą zauważyć, że muzyka jazzowa, która dla Zagajewskiego jest synonimem wspólnoty i — jednak — pospolitości („Zawsze ten sam thum pojawiał się na koncertach, równie brodaci słuchacze w równie grubych kożuchach"6), u Barańczaka sygnalizuje elitarność, wybór odległy od powszechnych gustów, jak w wierszu Hi-Fi o zapisanym cyfrowo koncercie Bill Evans Trio.

\section{2.}

Charakterystyczne, że takie ,ja” liryczne, które możemy identyfikować z bohaterem, nie jest stałym elementem poezji Barańczaka. Możemy raczej mówić o procesie stopniowej identyfikacji, począwszy od debiutanckiego tomiku ${ }^{7}$. Najpierw w miejsce bliżej nieokreślonego „my” pojawia się bohater jednostkowy, tajemniczy NN z tomu Sztuczne oddychanie, tytul kolejnego tomiku jest już zdecydowaną deklaracją Ja wiem, $\dot{z}$ e to niestuszne, po czym coraz częściej bohater staje się poetyckim porte parole samego poety, którego nie da się pomylić z przeciętnym obywatelem. Świadczą o tym „wydobyte z moich bagaży rysunki Jana Lebensteina” (Czyste ręce, s. 238), niemilosiernie przekręcane przez obcokrajowców nazwisko: „Banaczek” (Garden party, s. 301), „Mr. Baranazack” (Poczta, s. 318), czy ślady codziennych zajęć: „na biurku czekał George Herbert, / porzucony w pół rymu" (Grudzień 1976, s. 363). Nie zawsze też odautorskie ,ja” rysowane jest tak, by wywołać u nas choćby uśmiech. W takich wierszach, jak Grażynie (tekst poświęcony zmarłej żonie Jacka Kuronia, przyjaciółce poety) górę bierze powaga sytuacji:

Jeżeli kogoś podziwiałem, to właśnie ciebie.

Jeśli co było trwałe, to właśnie ten podziw.

[Grä̇ynie, s. 286]

Może jednak paradoksalnie ten wiersz jest — częściowo przynajmniej — kluczem do wskazania miejsca autoironicznej gry w poetyckim świecie Barańczaka? Jak rozu-

${ }^{4}$ A. Zagajewski, Obrona żarliwości, Kraków 2002, s. 48.

${ }^{5}$ Ibidem, s. 87.

${ }^{6}$ A. Zagajewski, $W$ cudzym pięknie, Kraków 1999, s. 122.

${ }^{7}$ O ewolucji podmiotu lirycznego Barańczaka zob. D. Pawelec, Dojśc do siebie. Wiersze Stanisława Barańczaka, w: idem, Debiuty i powroty. Czytanie w czas przełomu, Katowice 1988, s. 61-67. 
mieć bowiem deklarację rezygnacji z ironicznego dystansu kryjącą się w charakterystyce zmarłej przyjaciólki: „Tyle umiejętności. Taka perfekcja. Mówię poważnie”? Czy jest przypadkiem, że kilka wersów dalej ta powaga zostaje zaprzeczona: „Śmierć. Nie, to niepoważne, nie przyjmuję tego do wiadomości"? Rozbieżność jest oczywiście pozorna, pozostaje jednak pytanie, czemu akurat śmierć jest niepoważna i czemu akurat w tym momencie tak ważne staje się podkreślenie własnej powagi. Pierwsza intuicja podpowiada, że niepoważne (choć jeszcze wcale nie śmieszne) jest to, co jest nieoczywiste. Potwierdzają ją kolejne wersy, definiujące śmierć: „To przecież tylko nicość. Jakże takie nic ma stanąć między nami”. Być może więc kpina, tu zawoalowana, ma odsłaniać skandal zła i cierpienia, zaś koturn powagi pozwalałby go przezwyciężać?

Idąc tym tropem, warto przyjrzeć się kolejnym kreacjom Barańczakowego porte parole. Poszczególne maski zmieniają się zresztą w czasie, co ma swoje oczywiste źródło w biografii autora.

\section{3.}

Autor żartuje z siebie kolejno jako z Opozycjonisty, Intelektualisty (Poety, Tłumacza), Emigranta. Figury te zresztą łączą się często ze sobą w różnych konfiguracjach. Źródłem komizmu nie jest jednak sama postać, co raczej absurdalność lub nieadekwatność sytuacji, w jakiej się ona znalazła. $Z$ uśmiechem czytamy na przykład o tomiku wierszy schowanym w kalesonach, ale zdajemy sobie sprawę, że w momencie powstania wiersza był to popularny sposób szmuglowania tzw. bibuły.

I nikt mnie nie uprzedzil, że wolność

może polegać także na tym, że

siedzę komisariacie $z$ brulionem własnych wierszy

ukrytym (co za przezorność) w nogawce zimowej bielizny

[I nikt mnie nie uprzedzit, s. 252]

Sensowność tych działań zostaje dodatkowo podkreślona słowami: „cóż za przezorność”. To dopiero obecność przedstawicieli tajnej policji, którzy z całą powagą próbują rozgryźć ukryty sens listy zakupów („„włoszczyzna / puszka groszku / koncentrat pomid. ( ziemniaki»") powoduje, że bohater staje się jednym z aktorów „teatru absurdu”. Swój stosunek do całego zajścia określa też jednoznacznie słowami „skonam ze śmiechu”.

Wskażmy inne wiersze, w których Barańczak kontynuuje wątek opozycyjny: Wieczór autorkki, Czterdzieści osiem, Przywracanie porządku, Czyste ręce - to tylko część. Kolejne odsłony pokazują bohatera w sytuacjach, w których zachowanie godności jest możliwe - paradoksalnie - tylko dzięki parsknięciu śmiechem $z$ własnego losu. Jeżeli więzienie, to w doborowym towarzystwie "robociarza w kitlu" i „waluciarza w kożuchu” (Czterdzieści osiem, s. 254), jeżeli nalot, to bez szczególnych represji, „ponieważ są pewne formy” i „ponieważ jest pewien film” (Wieczór autorski, s. 235). W wierszu Czyste 
ręce (s. 238) podmiot wprost mówi o rozmijaniu się wyobrażeń i praktyki w kwestii stosowanych opresji:

Nie żebym się spodziewał plam krwi, smug potu, brudu [...]

A jednak

byłoby jakoś naturalniej,

gdyby na naszych wierszach, rysunkach, dziennikach i mózgach

pozostawili, choćby na pamiątkę,

swój niepowtarzalny (linie papilarne!) ślad.

Postawie Barańczaka, gdy pisze o swoim zaangażowaniu w działalność opozycyjną, zdaje się patronować postulat Herberta z Przestania Pana Cogito: „oglądaj w lustrze swą błazeńską twarz”. Uczciwe spojrzenie we własną twarz, gotowość nazwania własnych słabości po imieniu, choćby z przymrużeniem oka, pozwala spojrzeć równie uczciwie na okalającą, niewesołą rzeczywistość. Można by postawić dość typowe w przypadku twórczości Barańczaka pytanie, czy absurd własnej egzystencji ma u niego charakter historyczny, czy pozahistoryczny, przynależny każdej ludzkiej naturze. Tej pierwszej odpowiedzi zdaje się sprzyjać fragment wiersza N.N. zaczyna zadawać sobie pytania (s. 133):

Żyć w czasach wypełnionych nieustannym mruganiem, puszczaniem perskiego oka, $[\ldots]$

cóż się właściwie dzieje z nami, że się w to

wciąż bawimy? W te rytualne gesty, porozumiewawcze miny?

Gdy jednak czytamy:

ja, niewprawny jasnowidz, widzący czarno przed sobą, do upadłego będę targować się z kurzą ślepotą źle oświetlonych planet i nieoświeconych reżymów [Utożone po ciemku, s. 240] -

to domyślamy się, że ten „niewprawny jasnowidz, widzący czarno” pozostałby nim poza jakimkolwiek Tu i Teraz historii. Wlasna śmieszność, a tym samym własna niedoskonałość, jest argumentem przeciwko wszelkim założeniom systemów teoretycznie doskonałych.

\section{4.}

W latach osiemdziesiątych Barańczak pokazuje się już raczej w masce Poety i Emigranta. Moment ten, z całą jego specyfiką, trafnie uchwycił Tadeusz Nyczek, w kon- 
tekście tomu Atlantyda pisząc o izolacji Barańczaka od spraw społecznych, o jego niemożności współudziału we wspólnocie:

Tego typu udział został [...] aż podwójnie zaprzeczony. Raz, przez obcość poety w społeczeństwie, obcość organiczną, wynikającą z samego statusu poety, czyli osobnego. Dwa, przez egzystencjalne oddalenie. To dwukrotne zaprzeczenie będzie jednym $z$ najdotkliwszych doświadczeń autora i narratora ksiązki ${ }^{8}$.

Tym samym, zdaniem Nyczka, Barańczak w swych wierszach jawi się jako „ktoś inny. Obcy. Skądinąd”. Temat obcości, z różnymi wynikającymi z niego implikacjami moralnymi, stanie się w latach osiemdziesiątych tematem nadrzędnym tej poezji. Wiązać się z nim będą nierozerwalnie takie zagadnienia, jak: kontakt, dialog, spotkanie, a łączącą je zgrabnie metaforą okazuje się „widokówka $z$ tego świata”. Tym samym dokonuje się u autora Atlantydy charakterystyczne dla całej Nowej Fali przesunięcie akcentów, wielokrotnie wyrażane w formule „od polityki do metafizyki”. O ile jednak status Obcego pojawia się jako formuła autocharakterystyki wspólna "nowofalowcom” lat osiemdziesiątych, o tyle tylko w przypadku Barańczaka mamy do czynienia z podszyciem jej tonem kpiarsko-prześmiewczym.

"Samotność długodystansowca poezji” sygnalizowana jest kilkakrotnie, najdobitniej chyba w wierszu Grudzien 1976, wierszu o spotkaniu Poety z Krawczykiem Olgierdem, starym kawalerem o śmiesznych nawykach, szmuglującym bibułę:

siedziałem jak na szpilkach — na biurku czekał George Herbert, porzucony w pół rymu, ale co było robić,

Krawczyk Olgierd miał nad nim tę niewątpliwą wyższość, że był żywy, posiniaczony, niezwłoczny $[\ldots]$

Barańczak kpi z siebie znowu; siebie jako Poety, Translatora. Samo życie kolejny raz strąca go z piedestału — takie są konsekwencje potraktowania serio postulatu Nowej Fali „mów prawdę, do tego służysz”. W imię tej zasady bohater wiersza, w którym już bez pudła dostrzegamy samego Barańczaka, skazuje się na rozmowę ,przez pół godziny o lidze piłkarskiej i polityce”, kiedy to rozmówca ma czas „załzawić w pokoju powietrze / jednym i drugim klubowym, wypocić parę herbat”. Mamy więc do czynienia w tym wierszu z komizmem obu postaci (pan Krawczyk, przy całym swym cierpieniu — jednak narzucający swą obecność i pan Barańczak, przy calym swym wykształceniu i ogładzie - bez pomysłu, jak tej obecności zaradzić, umknąć). Komizm przeradza się jednak w dramatyzm, który wynika z braku możliwości udzielenia pomocy: „Co miałem powiedzieć istnieniu, które było Krawczykiem Olgierdem”, i dalej:

\& T. Nyczek, Strony obcości (Stanisław Barańczak), w: idem, Emigranci, Londyn 1988, s. 122. 
Nie umiałem,

nie było na to wspólnych słów. Tylko te płytsze, umowne, oględne, to, co się w takich sytuacjach mówi, co się bąka znad kartki.

Poeta przyznaje się więc do klęski na całej linii w tym, co stanowi istotę jego powołania: w szukaniu takich słów, które łączą, które niosą otuchę. Uczestnikiem tej klęski jest George Herbert - byłażby więc poezja jedynie czczą zabawą estetów? Dramatyzmu dodaje fakt, że nie jest to jakaś niespotykana, a raczej powtarzalna sytuacja (dwukrotnie użyte sformułowanie „na przykład Krawczyk Olgierd”).

Na powyższym przykładzie dobrze widać, że komizm u Barańczaka prowadzi również do odkrycia horror vacui poszczególnego istnienia, a jednocześnie zachowuje funkcję konsolacyjną. Barańczak odsłania ograniczoność prawd nazywanych niewzruszonymi (trudno nie powstrzymać się od żartu: nie wzrusza ich nawet nasze cierpienie) typu "«Kiedyś, po latach, Historia przyzna nam rację»” (Kiedyś, po latach, s. 288), by za prawdę nadrzędną uznać stwierdzenie, że „człowiek jest tylko człowiekiem”. Dlatego właśnie jego Opozycjonista jest „tylko Opozycjonistą”, a Poeta „tylko Poetą”. Za żartem z samego siebie kryje się przekonanie, że nigdy nie dorastamy do ról, jakie narzuca życie.

Czy rodząc się, mogłeś wiedzieć, żeś tylko w jedno się przedarł życie - że cała reszta czeka cię, obca i żywa? -

zapyta w wierszu Całe życie przed toba (s. 196). Kpina Barańczaka często - pozornie - uderza w świętości: etos dysydenta, rolę poety jako duchowego przywódcy narodu czy status inteligenta. Nie ma w tym geście jednak za grosz świętokradztwa, gdyż za każdym razem Autor obnaża przede wszystkim własne niedostatki.

Mówiąc o grze Barańczaka z mitologiami poety, nie sposób pominąć wiersza Drobnomieszczańskie cnoty (s. 354). Ta jawnie ironiczna, pozornie dezawuująca autora, poetycka autocharakterystyka powszechnie odczytywana jest jako paszkwil na Jacka Bierezina, „naczelnego kaskadera” literatury Nowej Fali'. W parze z niechęcią Barańczaka do poezji i poetów „przeklętych” idzie jednak formula samookreślenia:

\footnotetext{
${ }^{9}$ Odpowiedzią był wiersz-parafraza Jacka Bierezina Wielomiesięczne kryzysy. Te dwa teksty zazwyczaj zestawiane są ze sobą i każdy z nich brzmi wtedy o wiele mocniej (i dowcipniej). Warto jednak zwrócić uwagę na słowa Andrzeja Franaszka, który sugeruje inny typ lektury Drobnomieszczańskich cnót: „Tymczasem zasadnicza tonacja utworu jest inna, autorefleksyjna, przypomina niektóre późne wiersze Miłosza i oddaje najwyraźniej zasadniczy rys osobowości pisarza, zadającego sobie pytanie: «Skąd ten chorobliwy przymus, / aby udawać zdrowie, ustawiać przed zniszczeniami / bariery i makiety? Powody nie są w pełni jasne, nie zmniejsza to jednak pewności, iż nie należy odsłaniać swej rozpaczy, lęku, narzucać własnych duchowych piekieł innym ludziom. Czy jest to dowodem pychy, wiary, że poradzę sobie bez pomocy? A może raczej przekonania o daremności wysiłków, bo «trzeba by, na dobrą sprawę, / w każdej sekundzie życia powtarzać to samo ",ratuj”»?. Cyt. za: http://www.dziennik.pl/dziennik/ europa/article46320/Nic_bardziej_jasnego_od_sniegu_i_smierci.html (stan z 17. 02. 2007).
} 
Drobnomieszczańskie cnoty. Ja wiem, ja się ich wstydzę od lat poniżej poziomu: co za blamaż, nie mieć w biografii ani jednego rozwodu, dewiacji, większego nałogu, kuracji psychiatrycznej, burzliwego romansu na boku, pełnokrwistego podcięcia żył; jakieś szare gafy zamiast tęczowych skandali $[\ldots]$.

Barańczak definiuje siebie głównie przez opozycję do wizerunku artysty tragicznego. Operuje przy tym ironią w sposób podręcznikowy, wręcz schematyczny: dosłowne znaczenie jest przeciwne niezbyt głęboko ukrytej intencji. Tytułowe „drobnomieszczańskie cnoty", którymi sam się etykietuje, wpisują go w archetypiczny spór Filistra z Artystą. Gdy jednak przyznaje się, że jest „od lat poniżej poziomu”, to demaskuje elementy tragicznej biografii jako szereg pustych, teatralnych gestów. Skoro bowiem wyznaczają jakiś stały poziom, to wiemy, że są to gesty powtarzalne, rytualne wręcz. Ich schematyzm zostaje ostatecznie skompromitowany, gdy bohater z pozorną rezygnacją pisze o swoim życiorysie:

Ja wiem, to nie materiał na mit, kult, legendę, film z Robertem de Niro.

Jednak ten manifestacyjny, rażący wręcz schematyzm gry opartej na dwóch wizjach poety (które w odniesieniu do „nowofalowców” Jan Walc zamknął w formule „Buddenbrokowie i hippisi” ${ }^{10}$ ), traci na sile, gdy nasz autobiograficzny bohater odsłania motywy swej niechęci do demonstrowania własnego „bólu istnienia”. Bo jeżeli traktować je z całym należytym mu szacunkiem, należałoby „w każdej sekundzie życia powtarzać to samo «ratuj»". Tym samym — tu kolejny typowo Barańczakowy paradoks — pod powierzchnią żartu kryje się poważne rozpoznanie jednej z ułomności naszych czasów: cierpienie stało się towarem na rynku idei. Tymczasem przysługuje mu wewnętrzny rygor i powściągliwość, by nie sprowadzić go do maskarady czy gry pozorów.

Strategia zderzenia stereotypowego wyobrażenia z realiami życia powtarza się przy kolejnym - emigracyjnym - wcieleniu Barańczaka. Rola wygnańca-emigranta nie za bardzo odpowiada naturze autora Atlantydy. W świecie, gdzie ,jedyny problem znaleźć miejsce do parkowania" (Nowy Świat, s. 297) bohater musi czuć się absurdalnie jako „ekspert na skalę wschodnioeuropejską w kwestiach odmowy zeznań i mówienia między wierszami”. Podstawowym doświadczeniem okazuje się nieprzystosowanie i wyobcowanie. Z drugiej strony — oddalenie od kraju zdaje się nieść pewne profity,

10 Zob. J. Walc, Buddenbrokowie i hippisi (O peunym spotkaniu $w$ drugim obiegu), „Puls” 1992, nr 59, s. 34-45. 
a konstatacja tego faktu jest wspólnym doświadczeniem pokolenia '68, na co zwrócił uwagę Dariusz Pawelec:

Przeżywanie emigracji jest w dużej mierze równoznaczne z przė̇ywaniem samotności. Dla poetów pokolenia '68 nie oznacza ono bynajmniej cierpienia. Stanowi wręcz rodzaj zaskakującego odkrycia. Jest to samotność doceniona przez artystę po latach kolektywnego bytowania w świecie polityki ${ }^{11}$.

Barańczak będzie więc konsekwentnie kreślił swój autoportret jako Obcego, który jednak nie rysuje swej sytuacji w tonacji martyrologicznej; sam stwierdza: „nie używać słowa "wygnanie», bo to nieprzyzwoicie i bez sensu” (Nie u̇ंywać stowa „wygnanie”).

Zauważmy, że ta sama autoironia, która wcześniej pozwalała uniknąć mu nadęcia z tytułu pełnienia, bądź co bądź, szczytnych funkcji, teraz pomaga mu - wręcz przeciwnie - odnaleźć się w świecie, w którym jest całkiem anonimowy. Sygnalem zupełnej anonimowości są pytania zadane w luźnej, niezobowiązującej rozmowie:

„Przepraszam, nie dosłyszałem nazwiska?... Banaczek?...

Czy to czeskie nazwisko? A, polskie! To znaczy,

pan z Polski?"

[Garden party, s. 301]

W Polsce jako Poeta i Dysydent był kimś, teraz nagle stał się nikim.

Swoją sytuację określa precyzyjnie: „Nigdy jeszcze / tak niezdefiniowany, tak z boku, wygnany..." (Obsenvatorzy ptaków, s. 267), choć słowa te nabiorą innego wydźwięku, gdy dodamy, że padają w towarzystwie przypadkowych... ornitologów-amatorów, w „rezerwacie dzikiego ptactwa”. Są to „ludzie, którzy / na pytanie «Kim jestem?» mówią sobie: «jestem / obserwatorem ptaków»!”. „Mówią sobie”, czyli tak określają własną tożsamość, coś, co w przypadku kulturalnego Europejczyka wymaga sięgnięcia po arsenał takich pojęć, jak: tradycja śródziemnomorska, pamięć zbiorowa, zakorzenienie, poszukiwanie dialogu, małe ojczyzny... Wobec całego wysublimowania tego aparatu pojęciowego lapidarne sformułowanie swego miejsca na ziemi brzmi cokolwiek naiwnie. Warto zauważyć, że ten pogodny rodzajowy obrazek współgra z rozważaniami Miłosza na temat różnic pomiędzy Starym i Nowym Kontynentem. W Amerykanach dostrzega przede wszystkim wyznawców „ideologii naturalnej”. Nie po to jednak Barańczak przywołuje te słowa, by podbudować swoje (i nasze przy okazji) ego. Bo puenta tego wiersza brzmi:

11 D. Pawelec, Pokolenie '68 „na uygnaniu”, w: idem, Debiuty i powroty, op. cit., s. 68-84. Dalej Dariusz Pawelec zauważa, że jednak ,poeci pokolenia '68 nie uniknęli w swej twórczości toposów i tematów znamiennych dla literatury emigracyjnej, nie uniknęli również przyjęcia roli czy może strategii emigranta". 


\section{JESTEŚ TUTAJ: \\ wśród ludzi, obcych, ale jesteście — zaufaj — \\ po jednej stronie, współobserwatorzy \\ ptaków, pogody, innych rzeczy.}

Pozorna, zawoalowana kpina spełnia więc podobną rolę, co w wierszu Grudzień 1976. Jeżeli nawet obnaża słabości — i własne, i cudze — to nie w celu wystawienia ich na pośmiewisko. Jest to formuła otwarcia się na drugiego, budowanie tożsamości już nie przez dziedzictwo i pamięć, ale przez tworzenie relacji. Śmiech Barańczaka leczy, otwiera i buduje.

\section{5.}

Wskazane tutaj autokreacje Barańczaka z pewnością nie wyczerpują bogactwa jego twórczości, służyły raczej wskazaniu kilku punktów wspólnych, również w odniesieniu do jego humorystycznych talentów. Na osobne potraktowanie zasługuje chociażby Barańczak-Meloman. Zabrakło te ż jednego z najbardziej osobistych wierszy, ale te $\dot{z}$ zdecydowanie najśmieszniejszych - Alba lodówkowa - przekornie rubasznego hymnu miłości, gdzie w bohaterze też domyślamy się samego autora.

Wędrując przez jego teksty, wskazaliśmy kilka zasadniczych założeń operowania żartem wymierzonym w samego siebie. W pewnym uogólnieniu można powiedzieć, że autoironia:

1. pozwala Barańczakowi spojrzeć na siebie z dystansem;

2. jest formulą otwarcia na Innego;

3. odbrązawia mity (społeczne, historyczne, literackie), których bohater sam jest częścią;

4. szczególnie w późnych wierszach — otwiera na „metafizyczny skandal” zła i cierpienia.

Żeby jednak zakończenie nie wybrzmiało zbyt „belfersko”, pozwólmy jeszcze raz Barańczakowi puścić do nas oko - w tekście, który mieści w sobie wszystkie cztery powyższe strategie:

Stojąc przed witryna, w jej lustrzanym tle widzę kątem oka kubek w kubek mnie.

Wielkie podobieństwo, do zludzenia aż, gdyby nie ta zmięta, postarzała twarz; na wkroczeniu $w$ starość przyłapana twarz. [„Stojąc przed witryną, w jej lustrzanym tle...”, s. 416] 